\title{
Empowerment of elderly groups through the elderly health services assistance program
}

\author{
Lufthiani $^{1 *}$, Evi Karota ${ }^{1}$, Nunung F. Sitepu ${ }^{1}$ \\ ${ }^{1}$ Faculty of Nursing, University of Sumatera Utara \\ Email*: luvidam_lf@yahoo.co.id
}

\begin{abstract}
Health problems in the elderly begins with the process of deterioration of body cells, which causes a decrease in function and immune system so that it can increase risk factors for disease. Some diseases that are often experienced by the elderly include, hypertension, diabetes mellitus, rheumatism, gout, hearing loss, vision problems, osteoporosis, and others. These conditions will have an impact on increasing morbidity and mortality, declining quality of life, and increasing health financing. The method of implementing community service activities is carried out by educating health issues, providing guidance, counseling and mentoring to 20 elderly groups. The purpose of community service activities is to increase health care efforts which are expected to implement programs to create or improve the ability to live healthy in the community both individuals and groups to be able to solve various problems related to health improvement and disease prevention on an ongoing basis. Education is carried out with health education about general elderly diseases that often occur, namely Diabetes and Gout, then conduct guidance and counseling by dividing into groups, and provide assistance by teaching foot exercises and foot care. Results The implementation of community service activities shows the results that Good Knowledge about degenerative diseases $(85.0 \%)$, after the mentoring activities namely guidance, counseling, foot gymnastics simulation and foot care. Paired t-test results before and after the assistance was given p value of 0.007 . It is expected that the elderly group can be independent in efforts to prevent degenerative diseases that are focused on diabetes mellitus
\end{abstract}

\section{Keywords : Empowerment of Elderly Groups, Health Services Assistance}

\begin{abstract}
Abstrak
Masalah kesehatan pada lanjut usia diawali dari proses kemunduran sel-sel tubuh, yang menyebabkan terjadinya penurunan fungsi dan daya tahan tubuh sehingga dapat meningkatnya faktor resiko terhadap penyakit. Beberapa penyakit yang sering dialami lansia antara lain, hipertensi, diabetes melitus, rematik, asam urat, gangguan pendengaran, gangguan penglihatan, osteoporosis, dan lain-lain. Kondisi tersebut akan berdampak kepada peningkatan kesakitan dan kematian, kualitas hidup menurun, serta meningkatnya pembiayaan kesehatan. Metode pelaksanaan kegiatan pengabdian kepada masyarakat dilakukan dengan edukasi masalah kesehatan, melakukan bimbingan, konseling dan pendampingan kepada 20 orang kelompok lansia. Tujuan kegiatan pengabdian kepada masyarakat ini meningkatkan upaya pemeliharaan kesehatan yang diharapkan pelaksanaan program untuk menciptakan atau meningkatkan kemampuan hidup sehat pada masyarakat baik individu maupun kelompok untuk dapat memecahkan berbagai permasalahan yang terkait dengan peningkatan kesehatan dan pencegahan penyakit secara berkesinambungan. Edukasi dilakukan dengan penyuluhan kesehatan tentang penyakit lansia secara umum yang sering terjadi yaitu Diabetes dan Asam Urat, selanjutnya melakukan bimbingan dan konseling dengan membagi dalam beberapa kelompok, dan melakukan pendampingan dengan mengajarkan senam kaki dan perawatan kaki. Hasil Pelaksanaan kegiatan pengabdian kepada masyarakat ini menunjukkan hasil bahwa Pengetahuan Baik tentang penyakit degeneratif $(85,0 \%)$, setelah dilakukan kegiatan pendampingan yaitu bimbingan, konseling, simulasi senam kaki dan perawatan kaki. Hasil uji paired t-test pada sebelum dan sesudah diberikan pendampingan diperoleh nilai p 0.007 . Diharapkan kelompok lansia dapat mandiri dalam upaya pencegahan penyakit degeneratif yang difokuskan pada penyakit diabetes mellitus.
\end{abstract}

Kata kunci : Pemberdayaan Kelompok Lansia, Pendampingan Pelayanan Kesehatan 
Luthfiani et.al Empowerment of elderly groups

\section{PENDAHULUAN}

Lanjut usia (lansia) merupakan masa dimana individu dapat merasakan kesatuan, integritas, dan refleksi dari kehidupannya. Banyak orang yang dapat menikmati masa tua akan tetapi sedikit pula yang mengalami sakit dan sampai meninggal tanpa dapat menikmati masa tua dengan bahagia. Setiap orang menginginkan hidup bahagia, sehat dan mandiri saat masa tuanya, tetapi keinginan itu tidaklah selalu menjadi kenyataan. Pada kenyataan kondisi sesorang semakin bertambah usia maka proses kelemahan, keterbatasan dan ketidakberdayaan dikarenakan proses menua pasti akan terjadi. Saat ini jumlah lansia diperkirakan mengalami peningkatan dari tahun ke tahun, Indonesia pada tahun 1990-2025 akan mempunyai kenaikan jumlah lanjut usia sebesar 414\%. Berdasarkan data Biro Pusat Statistik tahun 2014, umur Harapan Hidup (UHH) di Indonesia untuk wanita adalah 73 tahun dan untuk pria adalah 69 tahun, dan pada tahun 2020 diperkirakan UHH akan meningkat menjadi 70-75 tahun. (Nugroho, 2000)

Peningkatan jumlah populasi lansia ini sejalan dengan meningkatnya berbagai macam penyakit degeneratif yang dialami oleh lansia. Pada usia diatas 65 tahun lansia sering mengalami gangguan kesehatan yang menyebabkan mereka kehilangan semangat, depresi dan merasa dirinya tidak berharga. Hal ini dikarenakan penurunan fungsi dari sistem tubuh melalui proses penuaan yang pasti akan dialami oleh lansia. Melihat berbagai kondisi lansia tersebut maka sangat diperlukan perhatian dan bimbingan secara intensif yang harus dipelajari, dihayati dan diamalkan dalam kehidupan sehari-hari. Dalam memberikan bimbingan dapat dilakukan dengan pendampingan dalam pelayanan kesehatan lansia secara berkesinambungan yang diharapkan adanya peningkatan perilaku sehat dan mandiri dalam upaya pencegahan penyakit lanjut.

Kecamatan Medan Sunggal merupakan salah satu dari 21 kecamatan di Kota Medan, Sumatera Utara, yang berbatasan dengan Kabupaten Deli Serdang. Luas wilayah Kecamatan Medan Sunggal $15.44 \mathrm{Km}^{2}$. Berdasarkan data jumlah penduduk pada tahun 2016 terdapat sebanyak 115.785 jiwa dengan jumlah rumah tangga 27.136 jiwa. Data yang diperoleh dari Profil Puskesmas Kota Medan tahun 2015 jumlah lansia mencapai 4.753 jiwa, dari data tersebut dinyatakan lansia yang berusia > 60 tahun hanya $55 \%$ cakupan pelayanan kesehatan lansia. (http://www.depkes.go.id). Kecamatan Medan Sunggal mempunyai 2 Puskesmas Induk dan 1 Puskesmas Pembantu. Hal ini dinyatakan masih kurangnya sarana pelayanan kesehatan yang dibutuhkan untuk meningkatkan upaya kesehatan masyarakat khususnya Lansia. Ligkungan III Kelurahan Sunggal juga belum terbentuknya Posyandu Lansia, sehingga kurang mendukung terhadap pencapaian derajat kesehatan lansia di daerah tersebut.

Kecamatan Medan Sunggal merupakan salah satu dari 21 kecamatan di Kota Medan, Sumatera Utara, yang berbatasan dengan Kabupaten Deli Serdang. Luas wilayah Kecamatan Medan Sunggal $15.44 \mathrm{Km}^{2}$. Berdasarkan data jumlah penduduk pada tahun 2016 terdapat sebanyak 115.785 jiwa dengan jumlah rumah tangga 27.136 jiwa. Data yang diperoleh dari Profil Puskesmas Kota Medan tahun 2015 jumlah lansia mencapai 4.753 jiwa, dari data tersebut dinyatakan lansia yang berusia > 60 tahun hanya $55 \%$ cakupan pelayanan kesehatan lansia. (http://www.depkes.go.id). Kecamatan Medan Sunggal mempunyai 2 Puskesmas Induk dan 1 Puskesmas Pembantu. Hal ini dinyatakan masih kurangnya sarana pelayanan kesehatan yang dibutuhkan untuk meningkatkan upaya kesehatan masyarakat khususnya Lansia. Ligkungan III Kelurahan Sunggal juga belum terbentuknya Posyandu Lansia, sehingga kurang mendukung terhadap pencapaian derajat kesehatan lansia di daerah tersebut. 
Luthfiani et.al Empowerment of elderly groups

Berdasarkan wawancara dan observasi langsung dengan mitra diperoleh permasalahan yang dihadapi mitra yaitu: Belum adanya kelompok lansia yang dapat menjadi wadah untuk saling berbagi informasi dan memotivasi dalam perilaku hidup sehat lansia, Masih kurang efektif pemanfaatan posyandu lansia dalam upaya pelayanan kesehatan dan pemberikan informasi tentang upaya pencegahan penyakit pada lansia, Belum terbentuknya posyandu lansia di lingkungan III Kelurahan Sunggal untuk melakukan kegiatan yang menunjang kesehatan lansia, seperti senam lansia, pemeriksaan fisik dan tekanan darah, Belum pernah dilakukan pelatihan dan bimbingan dalam program pendampingan pelayanan kesehatan lansia.

\section{METODE}

Metode pengabdian pada masyarakat ini dilaksanakan dengan memberikan informasi/ edukasi kesehatan kepada kelompok lansia tentang masalah kesehatan dan upaya pencegahan penyakit, melakukan bimbingan, konseling dan pendampingan, melakukan pemeriksaan kesehatan. Edukasi dilakukan untuk memberikan pengetahuan dasar kelompok lansia tentang masalah kesehatan dan upaya pencegahan penyakit. Pendampingan pelayanan kesehatan diawali dengan tahapan persiapan dengan mendata sumber pendukung lansia dari keluarga maupun kelompok lansia, selanjutnya pelaksanaan pendampingan dengan menyepakati pelaksanaan yang dilakukan secara berkelanjutan sampai terjadi penerapan dan perubahan perilaku dalam pola hidup sehat lansia. Kegiatan ini diawali dengan acara pembukaan oleh ketua Pengabdian Pada Masyarakat, kemudian perkenalan ketua dan anggota tim pengabdian pada masyarakat dan dilanjutkan dengan menjelaskan tahapan pelaksanaan kegiatan. Kegiatan ini dilakukan secara periodik hingga seluruh target terlaksana.

Metode pelaksanaan kegiatan pengabdian kepada masyarakat dilakukan dengan :

1. Pemeriksaan kesehatan umum: tekanan darah, pemeriksaan KGD dan Asam Urat

2. Pengisian Kuesioner Pre tes, untuk menilai pengetahuan dasar peserta tentang Penyakit Diabetes Melitus

3. Edukasi/ penyuluhan kesehatan kepada kelompok lansia tentang Bersama kita atasi Diabetes Melitus

4. Memberikan Bimbingan dan konseling tentang diabetes mellitus dan asam urat dilakukan dengan membagi peserta dalam 3 kelompok kecil dan dibimbing oleh 3 fasilitator/ narasumber

5. Melakukan pendampingan dengan mengajarkan peserta tentang senam kaki dan perawatan kaki

6. Pemberdayaan kelompok lansia dengan mengarahkan peserta untuk saling mengajarkan cara senam kaki dan perawatan kaki secara mandiri.

Partisipasi Mitra dalam pelaksanaan program ini adalah mencarikan informasi terkait dengan target dan kebutuhan dalam kegiatan. Informasi tersebut penting untuk menentukan besarnya anggaran yang diperlukan dalam pelaksanaan kegiatan. Selain itu mitra juga membantu mensosialisasikan program yang akan dilaksanakan pada kegiatan tersebut.

\section{HASIL DAN PEMBAHASAN}

Pelaksanaan kegiatan pengabdian kepada masyarakat di Lingkungan III, Kelurahan Sungg berjalan dengan baik, dengan jumlah peserta 20 orang lansia yang berusia $>55$ tahun, target yang 
Luthfiani et.al Empowerment of elderly groups

ditentukan sebelumnya yaitu kelompok lansia yang berusia >60 tahun. Sedangkan lansia yang berusia >60 tahun sudah tidak mampu lagi untuk mengikuti kegiatan tersebut. Kegiatan pengabdian kepada masyarakat dihadiri juga oleh Kepala Lingkungan III dan Ibu Lurah Kelurahan Sunggal.

Tabel 3.1 Distribusi frekuensi karakteristik responden $(n=20)$.

\begin{tabular}{|c|c|c|}
\hline $\begin{array}{c}\text { Karakteristik } \\
\text { Responden }\end{array}$ & Frekuensi & Persentase \\
\hline $\begin{array}{l}\text { Jenis } \\
\text { Kelamin } \\
\text { Laki-laki } \\
\text { Perempuan }\end{array}$ & $\begin{array}{c}5 \\
15\end{array}$ & $\begin{array}{l}25,0 \\
75,0\end{array}$ \\
\hline $\begin{array}{l}\text { Umur } \\
50-55 \text { tahun } \\
56-60 \text { tahun } \\
>60 \text { tahun }\end{array}$ & $\begin{array}{l}7 \\
7 \\
6\end{array}$ & $\begin{array}{l}35,0 \\
35,0 \\
30,0\end{array}$ \\
\hline $\begin{array}{l}\text { Penghasilan } \\
<2 \text { juta } \\
2-3 \text { juta } \\
>3 \text { juta }\end{array}$ & $\begin{array}{c}12 \\
6 \\
2\end{array}$ & $\begin{array}{l}60,0 \\
30,0 \\
10,0\end{array}$ \\
\hline $\begin{array}{l}\text { Pendidikan } \\
\text { SD } \\
\text { SMP } \\
\text { SMA } \\
\text { PT } \\
\text { Tidak } \\
\text { Sekolah }\end{array}$ & $\begin{array}{l}3 \\
5 \\
7 \\
3 \\
2\end{array}$ & $\begin{array}{c}15,0 \\
25,0 \\
35,0 \\
15,0 \\
2,0\end{array}$ \\
\hline $\begin{array}{l}\text { Suku Bangsa } \\
\text { Jawa } \\
\text { Batak } \\
\text { Melayu } \\
\text { Mandailing }\end{array}$ & $\begin{array}{c}7 \\
10 \\
2 \\
1\end{array}$ & $\begin{array}{c}35,0 \\
50,0 \\
10,0 \\
5,0\end{array}$ \\
\hline $\begin{array}{l}\text { Status } \\
\text { Pernikahan } \\
\text { Menikah } \\
\text { Tidak } \\
\text { Menikah } \\
\text { Janda/Duda }\end{array}$ & $\begin{array}{c}19 \\
0 \\
1\end{array}$ & $\begin{array}{c}95,0 \\
0 \\
5,0\end{array}$ \\
\hline $\begin{array}{l}\text { Informasi ttg } \\
\text { diabetes } \\
\text { Ya } \\
\text { Tidak }\end{array}$ & $\begin{array}{c}6 \\
14\end{array}$ & $\begin{array}{l}30,0 \\
70,0\end{array}$ \\
\hline
\end{tabular}


Luthfiani et.al Empowerment of elderly groups

Gambar 3.1 Distrribusi frekuensi Pre-tes kuesioner Pengetahuan tentang diabetes $(n=20)$

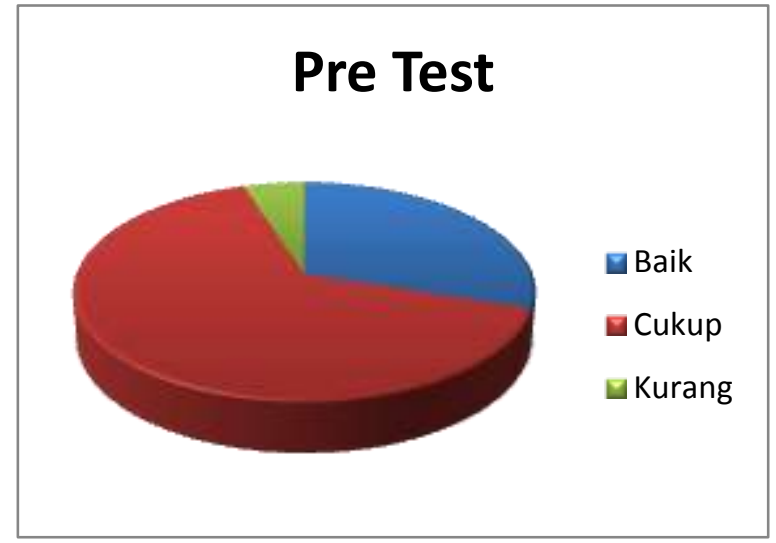

Keterangan :

Baik $=30,0 \%$, Cukup $=65,0 \%$, Kurang $=5 \%$

Gambar 3.2 Distribusi frekuensi Post-tes kuesioner pengetahuan tentang diabetes $(n=20)$

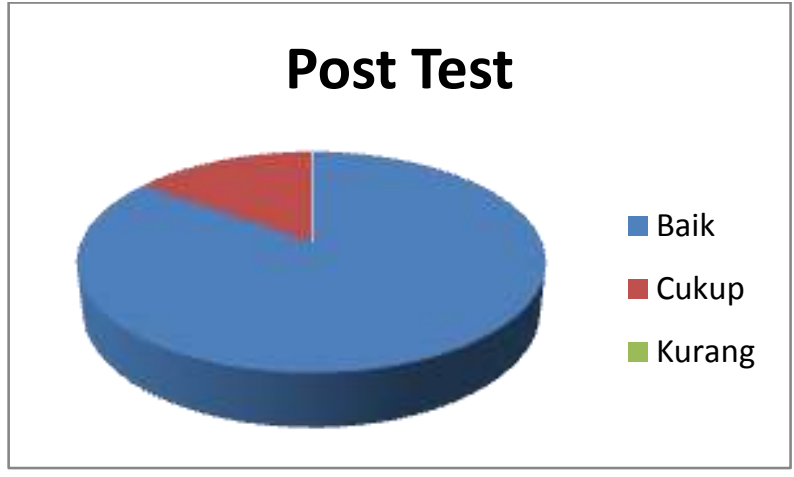

\section{Keterangan:}

Baik $=85,0 \%$, Cukup $=15,0 \%$

Tabel 3.2 Hasil Uji Paired t-tes sebelum dan sesudah dilakukan pendampingan

\begin{tabular}{cccc}
\hline Variabel & $\begin{array}{c}\mathrm{T}- \\
\text { Hitung }\end{array}$ & Sig & Mean \\
& & & \\
\hline Pre test & $-3,033$ & 0,007 & $-1,474$ \\
$\&$ Post & & & \\
Test & & & \\
\hline $\mathrm{N}=20$ & & & \\
\hline
\end{tabular}

nilai $\mathrm{p}=0,007(\mathrm{p}<0,05)$, yang berarti terdapat pengaruh pendampingan pelayanan kesehatan terhadap pengetahuan lansia 
Hasil kuesioner menunjukkan tingkat pendidikan lansia terbanyak pada SMP dan SMA dan terdapat $2 \%$ yang tidak bersekolah. Pendidikan memiliki korelasi yeng erat dengan pengetahuan, semakin tinggi tinggi tingkat pendidikan seseorang maka diharapkan semakin baik pengetahuannya, sehingga dapat lebih mudah menerima dan memahami informasi yang diberikan kepadanya. Suliha (2012) dalam (https://pdfs.semanticscholar.org/pdf) menyatakan bahwa pengetahuan seseorang dapat diubah dengan strategi persuasi yaitu memberikan informasi kepada orang lain dengan pendidikan kesehatan yang dilakukan dengan berbagai metode antara lain ceramah. Hasil kuesioner menunjukkan lansia terbanyak pada usia $>50$ tahun. Hal ini dinyatakan bahwa dengan bertambahnya umur seseorang maka akan terjadi perubahan pada aspek psikologis dan psikis sehingga tahap berpikir seseorang semakin matang dan dewasa, (Astuti, 2013)

Hasil kuesionar diperoleh sebanyak 70,0 \% lansia belum pernah mendapatkan informasi tentang penyakit diabetes mellitus. Berdasarkan Penelitian yang dilakukan oleh Riyambodo dan Purwanti (2017), menyatakan bahwa seseorang yang memiliki pengetahuan yang rendah cenderung sulit menerima dan memahami informasi yang diterima, sehingga orang tersebut akan acuh terhadap informasi baru dan merasa tidak membutuhkan informasi baru tersebut.

Berdasarkan hasil pre tes kuesioner pengetahuan diperoleh tingkat pengetahuan pada kategori cukup yaitu sebesar $(65,0 \%)$, sedangkan berdasarkan hasil post tes kuesioner pengetahuan diperoleh tertinggi pada kategori Baik (85\%). Hal ini menunjukkan adanya perubahan pengetahuan lansia sebelum dan sesudah diberikan edukasi/ pendidikan kesehatan, bimbingan dan konseling pada kelompok lansia.

Pendidikan kesehatan merupakan proses yang direncanakan dengan sadar untuk menciptakan peluang bagi individu-individu untuk senantiasa belajar memperbaiki, meningkatkan pengetahuan, dan keterampilan demi kepentingan kesehatannya (Notoatmojo, 2012). Sesuai dengan penelitian Yuliani (2015), menyatakan adanya pengaruh pendidikan kesehatan terhadap pengetahuan lansia dalam memanfaatkan posyandu lansia. Hal ini menunjukkan bahwa pengetahuan lansia tentang kesehatan dipengaruhi dari informasi yang didapat melalui pendidikan kesehatan dalam upaya merubah perilaku kesehatan. Menurut Notoadmojo (2010), menjelaskan salah satu faktor yang mempengaruhi pengetahuan yaitu informasi atau paparan media massa. Bahwa dalam memberikan informasi dan pendidikan kesehatan itu dapat meningkatkan pengetahuan dengan metode pendekatan secara langsung yang dapat dilakukan dengan bimbingan dan konseling. Hal ini disebabkan oleh bertambahnya informasi dan pemahaman lansia tentang upaya pencegahan penyakit. Menurut Notoadmojo (2007), pengalaman sebagai symbol pengetahuan merupakan suatu cara untuk memperoleh kebenaran pengetahuan dengan cara mengulang kembali pengetahuan yang diperoleh di masa lalu. Dengan metode bimbingan dan konseling yang dapat dilakukan secara berkesinambungan dapat memberikan perubahan bukan hanya pengetahuan tetapi lebih kepada perubahan perilaku.

Pencapaian tujuan pendidikan kesehatan akan lebih mudah dengan penggunaan media pembelajaran yang sesuai dan dapat meningkatkan kemudahan penerimaan informasi. Menurut Nies dan McEwen (2001) penggunaan alat bantu berupa tulisan akan lebih menghasilkan peningkatan pengetahuan daripada dengan kata-kata.

Pendampingan dilakukan dengan cara memberikan perhatian, menyampaikan pesan, menyemangati, mengajak,memberikan pemikiran/solusi, menyampaikan layanan/bantuan, memberikan nasihat, merujuk, menggerakkan dan bekerjasama. Hasil penelitian yang dilakukan oleh Abdilah (2016) di Banyuanyar menunjukkan bahwa pendampingan terbukti sebagai cara yang efektif untuk meningkatkan kepatuhan diet pasien diabetes mellitus. 
Luthfiani et.al Empowerment of elderly groups

Program pendampingan pada kegiatan pengabdian kepada masyarakat ini berupa memberikan pelayanan kesehatan dengan bimbingan, konseling terhadap masalah kesehatan lansia yang terfokus pada penyakit diabetes mellitus, dikarenakan masih banyak lansia yang belum mengetahui tentang penyakit diabetes dan upaya pencegahannya. Pendampingan juga dilakukan dengan mengajarkan simulasi teknik senam kaki dan perawatan kaki dengan memberdayakan kelompok lansia itu sendiri untuk dapat saling belajar bersama agar mandiri. Pada penelitian Delima dkk (2010) di wilayah Puskesmas Gamping II Sleman menunjukan ada pengaruh pendampingan terhadap terkontrolnya diabetes mellitus. Diabetes Melitus terjadi pada saat pola gaya hidup dan perilaku telah terbentuk dengan kokoh. Pendampingan merupakan bentuk edukasi, konseling dan motivasi untuk membantu penyelesaian permasalahan yang dihadapi pasien dalam pengelolaan penyakit di rumah.

\section{KESIMPULAN DAN SARAN}

Program Pendampingan pelayanan kesehatan lansia memberikan peningkatan pengetahuan dengan baik $(85,0 \%)$ melalui pendidikan kesehatan, bimbingan dan konseling.

Hasil uji statistik paired t-test diperoleh hasil (p 0,007) yang berarti terdapat pengaruh pada peningkatan pengetahuan dan keterampilan sebelum dan sesudah dilakukan pemberian pendampingan pelayanan kesehatan. Kegiatan pendampingan juga dilakukan dengan mengajarkan simulasi teknik senam kaki dan perawatan kaki, diharapkan kelompok lansia dapat mandiri dalam upaya pencegahan penyakit degeneratif yang difokuskan pada penyakit diabetes mellitus.

Dengan adanya program pemberdayaan kelompok lansia melalui program pendampingan pelayanan kesehatan lansia, diharapkan mampu meningkatkan upaya pencegahan penyakit degeneratif sehingga kelompok lansia dapat hidup produktif dan mandiri.

\section{UCAPAN TERIMAKASIH}

Penelitian ini dibiayai oleh Lembaga Pengabdian Kepada Masyarakat Universitas Sumatera Utara sesuai dengan Kontrak pelaksanaan Pengabdian Talenta Universitas Sumatera Utara Skema Pengabdian Mono Tahun Dosen Muda Tahun Anggaran 2019. Oleh karena itu, diucapkan terima kasih kepada Rektor Universitas Sumatera Utara atas dukungan dana dan fasilitas yang diberikan. Terima kasih juga kepada Mitra pada kegiatan pengabdian ini.

\section{DAFTAR PUSTAKA}

Abdilah, A.D (2016). Pengaruh Pendampingan terhadap Kepatuhan Diet pada Penderita Diabetes Melitus Tipe-2 di Wilayah Puskesmas Batuanyar, Surakarta. http://digilib.stikeskusumahusada.ac.id

Akhmadi. (2009). Permasalahan Lanjut Usia (Lansia). Yogyakarta: Graha Ilmu

Astuti, Y., Sumardiyono, W.B., (2013). Perilaku Hidup Bersih Dan Sehat (PHBS). Revisi II. Surakarta: Kementerian Pendidikan dan Kebudayaan Fakultas Kedokteran Universitas Negeri Surakarta.

Dinas Kesehatan Kota Medan. (2016). Profil Kesehatan Kota Medan. http://www.depkes.go.id 
Luthfiani et.al Empowerment of elderly groups

Kemensos RI. (2014). Modul Pendampingan Sosial Lanjut Usia. Jakarta.

Kementerian Kesehatan RI. (2015). Pelayanan dan Peningkatan Kesehatan Lanjut Usia. Jakarta. http://www.depkes.go.id

Lembaga Pengambdian Kepada Masyarakat (LPKM). (2019). Panduan Penyusunan Proposal Pengabdian Kepada Masyarakat. Edisi 3. Universitas Sumatera Utara. https://simabdimas.usu.ac.id

Nies, M.A., \& McEwen, M, (2001). Community health nursing: Promoting the health of population (3rd ed.), USA: W.B. Saunders Company.

Notoatmodjo S. (2007). Promosi Kesehatan dan Ilmu Perilaku. Jakarta: Rineka Cipta.

Notoatmodjo, S. (2012). Promosi Kesehatan dan Perilaku Kesehatan. Jakarta. Rineka Cipta.

Padila. (2013). Keperawatan Gerontik. Yogyakarta: Nuha Medika

Riyambodo, B., dan Purwanti, OS. (2017). Hubungan antara Tingkat Pengetahuan dengan Tingkat Distres pada Pasien Diabetes Melitus di RSUD Dr. Moewardi, Surakarta. Diakses dari $\underline{\text { http://eprints.ums.ac.id }}$

Suliha. Dkk (2012). Pendidikan Kesehatan dalam Keperawatan. Jakarta: EGC. https://pdfs.semanticscholar.org/pdf

Yuliani. (2015). Pendidikan Kesehatan terhadap Pengetahuan Lansia. http://repository.usu.ac.id 